\title{
Beware of what you eat: small bowel obstruction caused by freekeh bezoars
}

\author{
Faisal Al-Rashid, Abdulrazzak Al-Hariri, Abdul-Wahed Nasir Meshikhes
}

Department of Surgery, King Fahad Specialist Hospital, Dammam, Eastern Province, Saudi Arabia

\section{Correspondence to}

Dr Abdul-Wahed Nasi Meshikhes,

meshikhes@gmail.com

\section{DESCRIPTION}

A 21-year-old girl was admitted as an emergency with a $22 \mathrm{~h}$ history of severe colicky central abdominal pain and repeated vomiting. She was passing flatus only, and denied any history of similar

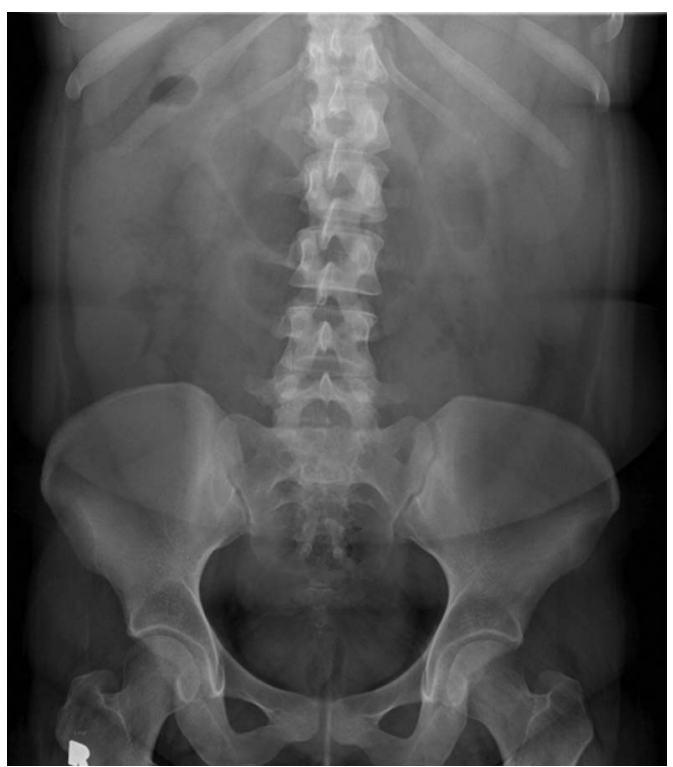

Figure 1 A plain abdominal X-ray (supine position) showing dilated loops of small bowel indicating a small bowel obstruction. symptoms or abdominal operations. She reported eating freekeh the night before presentation. Clinically, she was afebrile, with tachycardia (104 bpm). The abdomen was mildly distended with deep tenderness in the upper abdomen, but no detectable external hernias. Routine blood tests were normal. An abdominal X-ray revealed dilated loops of small bowel (figure 1). CT scan showed mild dilation of the jejunum down to an ovoid intraluminal lesion with mottled gas pattern at the site of obstruction with an abruptly collapsed terminal ileum beyond the lesion (figure 2). She was treated conservatively with a plan to operate if obstruction persists after $24 \mathrm{~h}$. Some $12 \mathrm{~h}$ later, she passed a large amount of stool which contained innumerable grains, and the obstruction was relieved.

Freekeh is a traditional Middle Eastern dish consisting mostly of specially roasted green wheat. It is believed to have high fibre content as compared to other grains. The literature is full of cases of small bowel obstruction due to phytobezoars composed of various indigestible food particles. ${ }^{1-3}$ However, acute small bowel obstruction due to ingestion of a Middle Eastern dish such as freekeh has never been reported before. The treatment is usually surgical. However, in this case of freekeh bezoar, a short period of conservative treatment after ingestion of gastrograffin contrast, proved beneficial and averted surgical intervention.

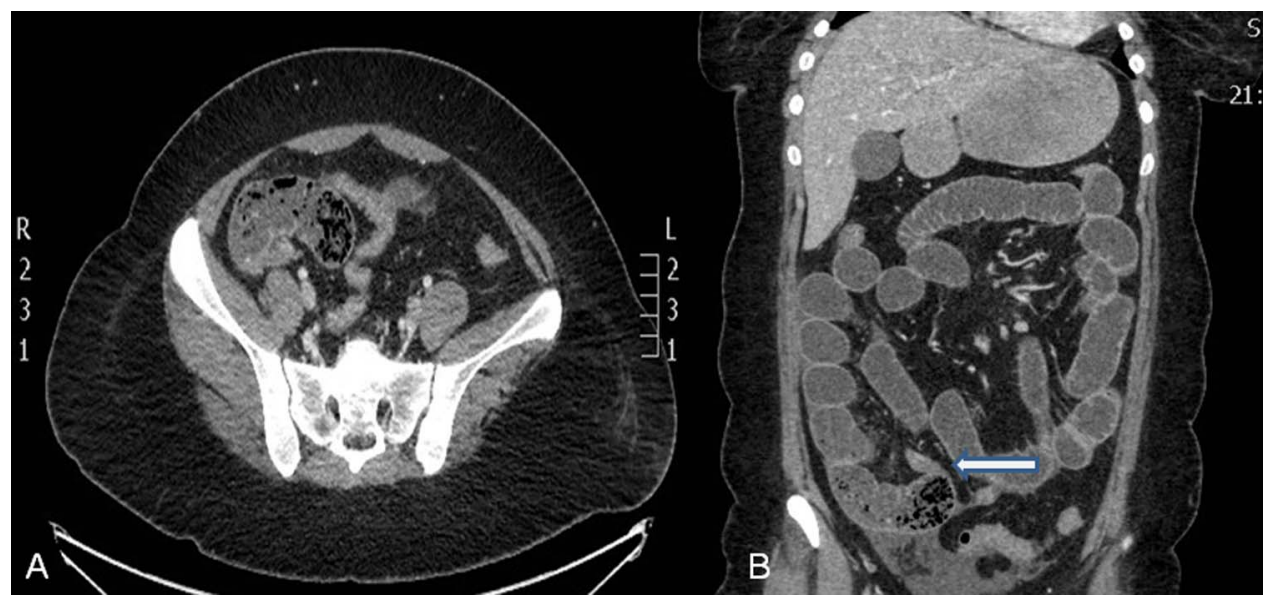

To cite: Al-Rashid F, AlHariri A, Meshikhes A-WN. BMJ Case Rep Published online: [please include Day Month Year] doi:10.1136/ bcr-2013-201444
Figure 2 Transverse (A) and coronal (B) images of a CT scan of the abdomen showing mild dilation of the small bowel loops down to the level of proximal ileum with an ovoid intraluminal mass lesion at the site of the obstruction. The terminal ileum is abruptly collapsed beyond the lesion ( $\mathrm{B}$; arrow). 


\section{Learning points}

- Acute small bowel obstruction may occur after the ingestion of the Middle Eastern dish of freekeh.

- A CT scan of the abdomen with oral gastrograffin contrast is helpful in diagnosis and can actually be therapeutic in some cases.

- A short period of conservative treatment is worthwhile, as it may prove beneficial and avert surgical intervention.

- Failure to respond to conservative treatment necessitates exploratory laparotomy.
Contributors FA-R wrote the case history. AA-H searched the literature. A-WNM wrote the final draft and was the primary surgeon managing the case.

Competing interests None.

Patient consent Obtained.

Provenance and peer review Not commissioned, externally peer reviewed.

\section{REFERENCES}

1 Lee JF, Leow CK, Lai PB, et al. Food bolus intestinal obstruction in a Chinese population. Aust N Z J Surg 1997;67:866-8

2 Harries K, Edwards D, Shute K. Hazards of a 'healthy' diet. Ann R Coll Surg Engl 1998:80:72.

3 Serrano KD, Tupesis JP. Small bowel obstruction from potato and broccoli phytobezoar mimicking mesenteric ischemia. J Emerg Med 2013:44:79-81.

Copyright 2013 BMJ Publishing Group. All rights reserved. For permission to reuse any of this content visit http://group.bmj.com/group/rights-licensing/permissions.

BMJ Case Report Fellows may re-use this article for personal use and teaching without any further permission.

Become a Fellow of BMJ Case Reports today and you can:

- Submit as many cases as you like

- Enjoy fast sympathetic peer review and rapid publication of accepted articles

- Access all the published articles

- Re-use any of the published material for personal use and teaching without further permission

For information on Institutional Fellowships contact consortiasales@bmjgroup.com

Visit casereports.bmj.com for more articles like this and to become a Fellow 